Climate Change and Agriculture in the Northeast:

\section{Teamwork, Responses, and Results}

This article is the second in a four-part series for Passages discussing how the agricultural community can better understand and address a changing climate. PASA was recently awarded a U.S. EPA Environmental Justice grant (\#96335501) for educational programs related to climate change and agriculture. This grant supports this Passages series, several field days and webinars, and pre-conference tracks at the recent 25th Farming for the Future conference. Join us as we explore Farming in a Changing Climate.

\section{Authors:}

Daniel Tobin, Instructor, Penn State University and USDA Northeast Climate Hub

Erin Lane, Coordinator, USDA Northeast Climate Hub

Ron Hoover, On-farm research coordinator, Penn State University

\section{Acknowledgments:}

Special thanks to John Lea-Cox the Stutzman family, and Joanna Tarrazi for providing information for this article.

\section{Climate change and agriculture in the Northeast}

In October 2012, Hurricane Sandy ravaged the east coast, causing billions of dollars in damage. Fortunately for farmers in the northeast, most of the summer crops had already been harvested but localized damage occurred: flooding in fields, electric outages, and beehives washed away.

While super storms like Sandy are not common occurrences, climate change is expected to bring about similar — and more frequent - extreme precipitation events that will likely have detrimental impacts to agricultural production through flooding, crop damage, soil erosion, and delayed plantings and harvests. While scientists warn that no single weather event can be attributed to climate change, a trend of more frequent severe storms can. And since the mid1900s, the northeastern U.S. has experienced more extreme precipitation events than any other region in the country (Hayhoe et al., 2007).

The impacts of a changing climate on agriculture in Pennsylvania and the northeast do not stop at severe weather events. For example, shorter, warmer winters may mean more intense insect pest invasions during the following growing season, and fruit farmers may experience early fruit tree blooms, only to be damaged by a subsequent frost. Hotter summers, drought conditions, and water stress may combine to harm animal and crop production. Data show that the average annual temperature across the northeast is on the rise (Kunkel et al., 2013). As these changes occur, farmers may also identify some new possibilities for their production. For example, earlier springs and longer growing seasons may mean that farmers are able to introduce new varieties and even increase yields (Wolfe et al., 2011).

The difficulty with climate change is its variability and unpredictability. While scientists have robustly documented that changes in the climate are occurring, they also readily admit that a great deal of uncertainty still exists. How quickly will temperature increase? Does a tipping point exist when changes will accelerate very quickly? What does the future look like in 20,50 , or 100 years?

What is clear is that change is happening and many witnesses are observing and responding to these changes. In the last issue of Passages, Mike Finewood wrote specifically about farmers and scientists and the different ways they understand these changes as outcomes of climate change. Although scientists are seen as the experts, farmers also hold invaluable knowledge that is crucial to productively adapt to climate change. To confront the challenge of climate change, these groups must work together.

Efforts across the Northeast are beginning to combine multiple sets of knowledge to proactively adapt to changes in the climate. PASA, for example, is taking an active role in assisting farmers to develop strategies for adapting to climate change. Using a grant though the EPA Environmental Justice Program, PASA is conducting field days where farmers and scientists come together to share knowledge and experiences on key adaptation strategies like building soil health. The U.S. government is also working to bring together the knowledge of farmers, university researchers and extension agents, and non-profit organizations. In 2013, the U.S. Department of Agriculture (USDA) launched their Regional Climate Hubs. The USDA Northeast

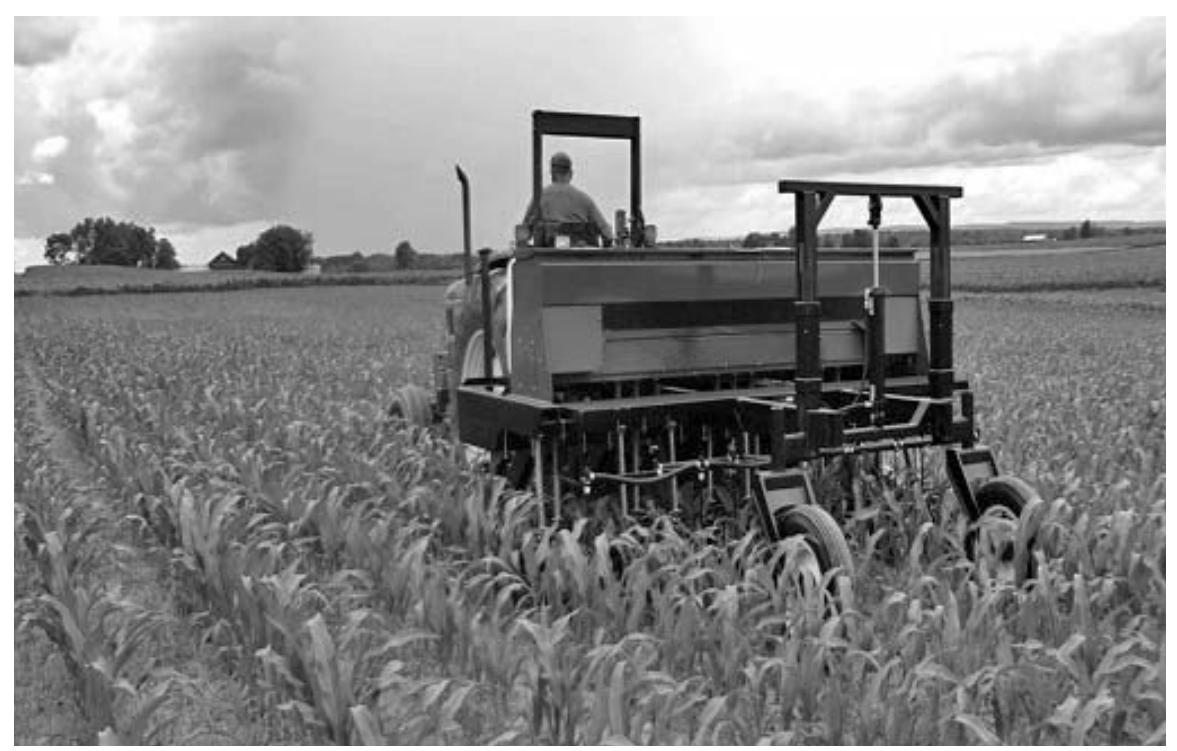

Interseeding a cover crop into a cornfield. Photo credit: Chris Houser (2013). 
Climate Hub works in collaboration with land-grant universities, state and federal agencies, non-profit and private partners, farmers, and foresters to identify and develop tools and outreach programs that relevantly and appropriately assist land managers to make informed decisions to adapt to and mitigate the effects of climate change.

As the USDA Northeast Climate Hub has engaged in this work, it has come across innovative regional efforts. Sometimes the ideas begin with farmers and other times within the university, but at some point, they always benefit from collaboration and cooperation. The following examples highlight the ways that different experts - farmers, researchers, extension agents, etc. - are working together to confront changes in the climate.

\section{Maintaining soil health through cover cropping}

As heavy rainfall events and moderate droughts become the norm, the negative impacts from weather on farm productivity are occurring more frequently. For farmers in the northeast, the increased frequency of intense rains often causes concern about soil erosion. Numerous practices exist that can help minimize soil loss and also aid in improving soil quality. One option is cover cropping, which has been rapidly increasing in popularity across the northeast. In addition to protecting the soil, cover cropping can help dairy and livestock producers grow more feed, keep fertility nutrients on the farm and out of ground and surface waters, and increase the soil's water-holding potential which can pay dividends during years when summer droughts occur.

Conventional farmers, who recognize the benefits of reducing tillage and planting cover crops, typically rely on herbicides to chemically control cover crops prior to the establishment of their next crop. Organic farmers, avoiding the use synthetic herbicides, often rely on tillage to destroy their cover crops and to control weeds that might be present in fields prior to new crop establishment. But tillage comes with numerous and considerable costs such as tractor fuel, replacement parts, time, and soil quality.

While several strategies exist for organic farmers to reduce tillage on their

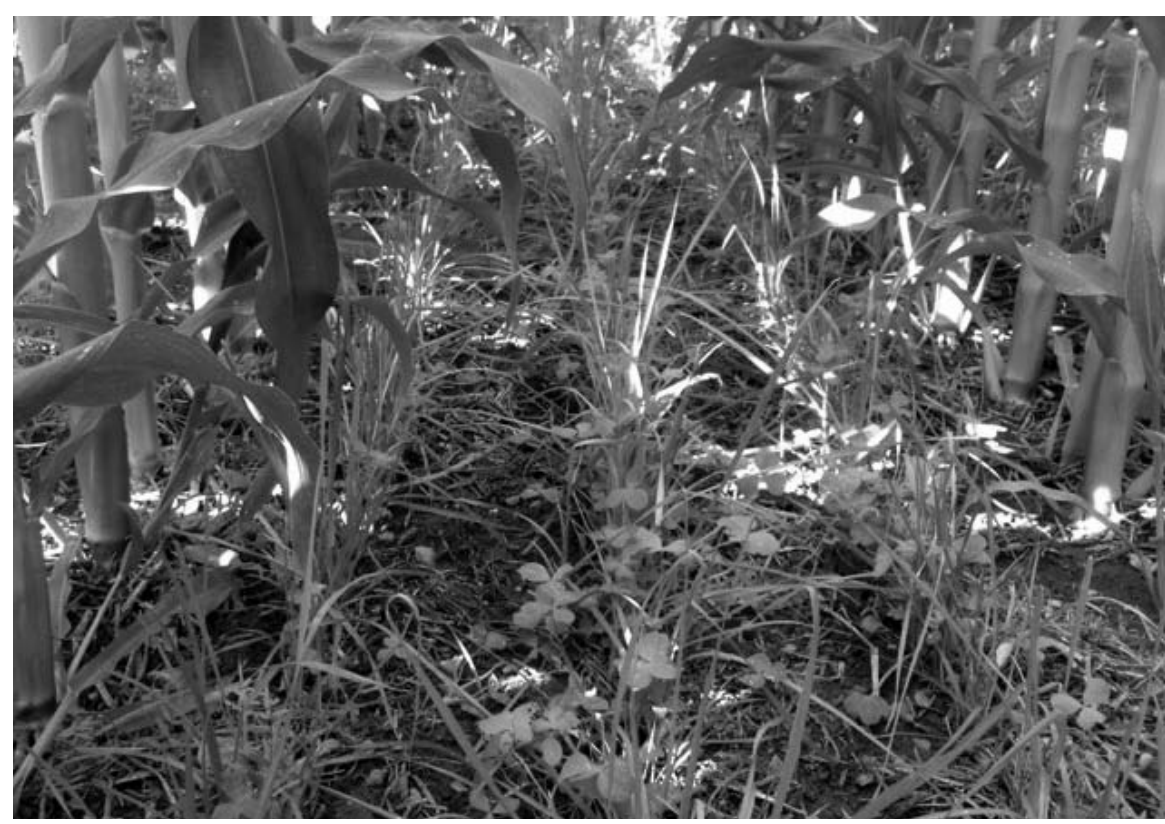

Cover crop emerging in a corn field, 28 days after annual ryegrass, red clover, and radish seed were interseeded in a cornfield. Photo credit: Ron Hoover (2015).

farms, the interseeder, a high clearance no-till drill that allows cover crops to be planted into standing annual crops (usually corn), is one that has received extensive attention from Penn State University. The interseeded cover crop is typically drilled when a corn crop has 46 leaf collars, which is early enough to allow the cover crop to become established well enough that it can survive the nearly two months of heavy shade prior to corn maturation, but not so early that the cover crop becomes competitive with the corn.

Several benefits can be realized from interseeding. A cover crop can be established and can produce biomass even before the grain crop is harvested. Therefore, the tillage that typically occurs after grain harvest but prior to cover crop planting is eliminated. In addition, in short season regions or during those years when grain harvests are delayed, drilling a cover crop after grain harvest may be impractical, so interseeding addresses that problem as well. Together with farmers, and supported by a USDA/ NIFA Organic Agriculture Research and Extension Initiative grant, Penn State researchers and extension educators have just completed the first of several years of on-farm and experiment station research to evaluate the potential for interseeding on organic grain farms. Across several certified organic farms in central Pennsylvania, experiments are being con- ducted to identify the best way to manage grain crops and interseed cover crops.

Though many citizens across the country are increasingly accepting that changes in the climate are occurring, many farmers are concerned about the economic impacts of adapting to these changes. While these concerns are valid, examples like the interseeder experiment demonstrate that some adaptation strategies can be developed that are both economically and environmentally beneficial. Although the results of the experiment are not yet established, the team of farmers, researchers, and extension educators are looking for solutions so that farmers can simultaneously pursue a bountiful grain harvest and improve soil health.

\section{Innovative Mobile Wooden High Tunnels} reduce risks associated with variable weather is with high tunnels. The passive solar structures are designed to extend the growing season and protect crops from potentially damaging conditions like temperature fluctuations, precipitation, frost, wind, insect pests, and disease. Typically, high tunnels have been simple, plastic-covered, tubular steel structures that can be costly or difficult to vent or move. Understanding the benefits and shortcomings of these traditional high continued on page 12
Another important way that farmers 


\section{Climate Change}

continued from page 11

tunnels, farmers, researchers, and the USDA are joining forces to improve the design of high tunnels.

In Sangerville, Maine, for example, an innovative mobile wooden high tunnel has been installed at Stutzman's Farm. The tunnel's framework is constructed of locally-milled Maine cedar, which is cost effective and supportive of the local economy. The design includes wheels for mobility and the structure is arch-shaped, helping it to shed snow and ice effectively. The shape also allows crops to be planted very close to the inside edge to maximize the growing space. In the colder months, a double layer of polyethylene film is inflated for insulation using a low powered fan, the only equipment in the high tunnel that requires electricity. Both sidewalls have doors that can be opened for ventilation and farm equipment. The high tunnel temperature is managed passively with solar gas cylin- ders, which open both the skylights and the side door louver vents.

Innovative as the high tunnel is, it would not have come to fruition without the partnership that has been established. Sunny Stutzman of Sunny Skies Design, in collaboration with University of Maine's Advanced Engineered Wood Composites Center, designed the high tunnel. Their efforts were contracted by the Piscataquis County Soil and Water Conservation District that received funds for the project through a USDA Natural Resources Conservation Innovation grant. The high tunnel was tested over a two-year period of farm trials at the Stutzman's and tested for structural integrity by the University of Maine's Advanced Structures Composites Center.

While this particular high tunnel design is currently in the pipeline to make more widely available to farmers, studies elsewhere have shown the benefits of high tunnels. For example, Demchak (2009) documented that cultivating red raspberries in high tunnels in Pennsylvania increased yields of marketable berries by 2-3 times. In Maine, as the Stutzmans, the University of Maine, the Piscataquis County Soil and Water Conservation District, and the USDA have come together, they have designed a wooden high tunnel that is a model for farmers across the northeast hoping to reduce their risk to weather events. The conservation district is now working to identify a manufacturer that can produce seasonal high tunnels based on this prototype model, and thereby bolster both the agriculture and the wood products industries in Maine.

\section{Water conservation with farm smart sensors}

If, as scientific predictions indicate, average temperatures tick upward in the northeast and drought conditions become more frequent during the growing season, water stress will likely present another concern for many farmers. Researchers from the University of Maryland are developing and implementing wireless sensor technologies to assist farmers to make better water manage-

\section{Insight. Advice. Priceless. New from ACRES U.S.A.}

\section{The Salatin Semester A Complete Home Study Course in Polyface-Style Diversified Farming}

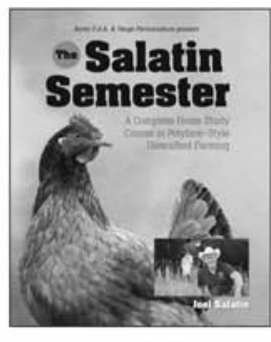

JOEL SALATIN

WITH DANIEL SALATIN AND THE ECO-FARMERS' FORUM; PRODUCED BY VERGE PERMACULTURE

This amazing multimedia production conveys the Salatin family's methods of profitable diversified farming like no other. The live presentations are presented in DVD video; the audio interviews with Q\&A are in digital audio; and the myriad questions and answers from the resulting discussion are transcribed and edited in a detailed reference guide.

\#7413 • 12 NTSC-DVDs, data/audio

disc, book $\cdot \$ 249.00$

\#7413PAL • 12 PAL-DVDs, data/audio

disc, book $\bullet \$ 249.00$

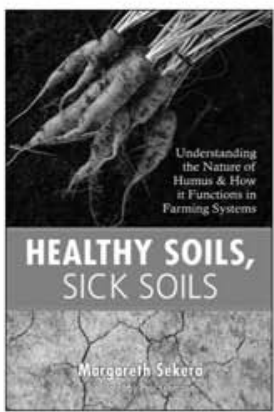

Healthy Soils, Sick Soils

\section{MARGARETH}

SEKERA

Now available in English for the first time, this popular 1943 treatise on biology and biologically correct working of soil from the pen of the famous soil scientist Prof. Dr. Franz Sekera, carefully edited and expanded by his wife, scientist Margareth Sekera, over the years, has long been beloved by farmers and soils scientists in its original German. Starting with the basic concepts of "tilth" and "soil structure" and moving along to the symptoms of unhealthy soil and the behavior of plants on non-friable fields, Sekera investigates the complex interrelationships in the soil as well as the practical measures to preserve and improve soil tilth. $\# 7415 \cdot$ Softcover $\cdot 160$ pages $\cdot \$ 20.00$

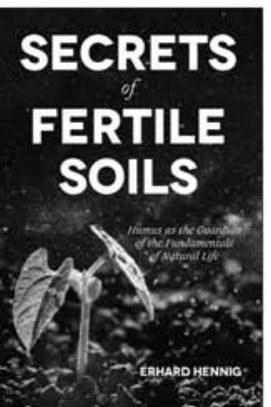

\section{Secrets of Fertile Soils}

ERHARD HENNIG

This stimulating book provides a highly practical window into the complex, interdependent relationships between soil, plants, animals, and human beings, including special insight into the fascinating life cycle of healthy soils and the imminent dangers we face should their existence become threatened. Translated from its original German, this book will help farmers everywhere understand

humus better.

\#7414.

Softcover -

198 pages.

$\$ 24.00$

\section{SUBSCRIBE TO ACRES U.S.A. MAGAZINE - \$29 FOR 12 MONTHLY ISSUES}

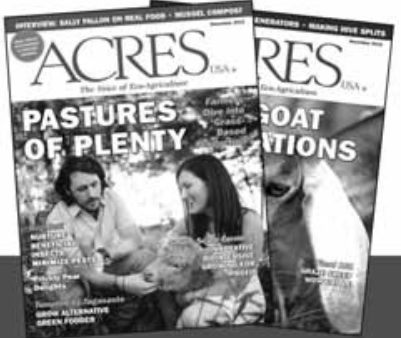




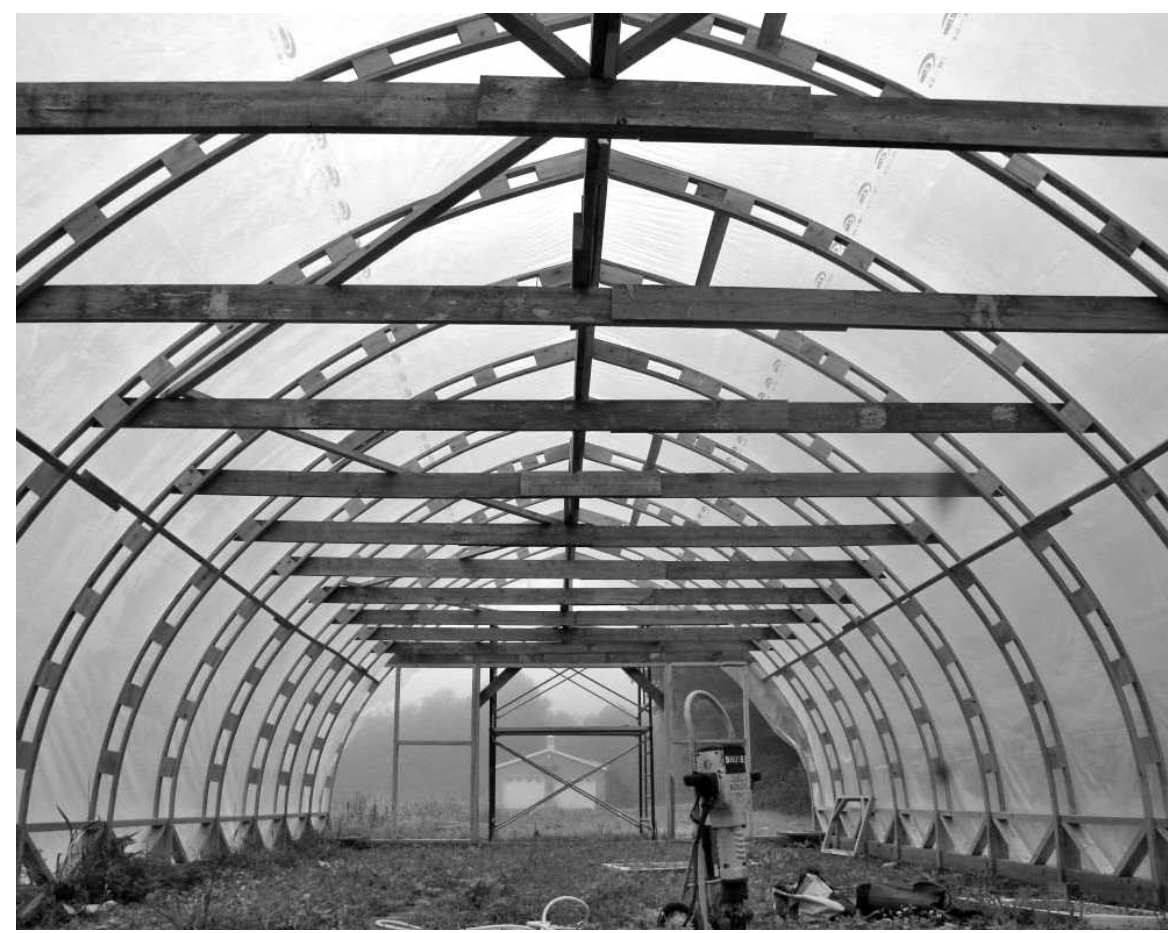

A few efforts to proactively respond to a changing climate include cover crops, innovative high tunnels (as pictured here) and farm smart sensors.

ment and environmental decisions with a changing climate. With funding from USDA grants, Dr. John Lea-Cox, Professor and Extension Specialist in the Departments of Plant Science and Landscape Architecture, leads a team of researchers focused on providing realtime information for farmers to make more informed decisions about their own practices.

According to Lea-Cox, "we use sensors to measure changes in soil moisture. Once this information is captured, we use computer software to provide intuitive graphs, alerts, irrigation scheduling and other tools for each farm site via the internet - directly to anyone who has access to the website." The importance of Lea-Cox's approach is that it provides specific information for farmers' individual landscapes.

The information that the online tool provides to farmers has been effective in assisting farmers to make water management decisions. Using automated soil moisture monitoring, Waverly Farm, a wholesale nursery in Maryland, adjusted its water application to reflect actual soil moisture and as a result, reduced the number of times irrigation needed to be applied by over one-half (Faulring, 2014). Sensor technology alerts farmers only when soil moisture drops below a certain level when irrigation is needed. Lea-Cox explains that without the kind of precision that the sensor technology provides, "sometimes, we totally miscalculate how much water it takes to replenish water in the root zone - and that is how we lose most of our water." The benefits of incorporating such information into decision-making can be substantial. Lea-Cox estimates that the potential water savings reach between 40-70\%, helping farmers save time, money, and energy, all the while adapting to potential effects of the changing climate.

\section{Proactive Agriculture in a changing climate}

Together farmers, scientists, nonprofits, state and federal agencies, local governments, and citizens can come together to ensure that agriculture adapts to climate change in innovative and productive ways. These types of efforts to proactively respond to a changing climate is sometimes called climate-smart agriculture, or agriculture that sustainably increases productivity while adapting to climate change and mitigating greenCover crops, innovative high tunnels, and farm smart sensors are only a glimpse into the impressive efforts that are underhouse gas emissions (Lipper et al., 2014). way. Solutions related to dairy and poultry management, flooding and frost, insect pest and pathogen invasions, and drought conditions are undergoing experimentation by farmers and being pursued by researchers.

Not everyone may agree on the best adaptation practices all the time, but as opposed to rigid guidelines, a whole suite of options are being developed that will allow individuals to pick and choose what best works for them. But being proactive in ways that have both an economic and environmental outlook will determine agriculture's success in responding to changes in climate. With collaboration and cooperation, the northeast can meet the challenge to maintain and improve production. The biggest risk is not climate change itself; it is being passive as these changes occur.

\section{Citations}

Demchak, K. (2009). Small fruit production in high tunnels. HortTechnology, 19(1), 44-49.

Faulring, J. (2014). Driving down irrigation costs — part II. FreeState News. Accessed at http://issuu.com/ marylandnurserylandscapeassn/docs/free_state_winter_2014_web.

Hayhoe, K., Wake, C.P., Huntington, T.G., Luo, L.F. Schwartz, M.D., Sheffield, J., Wood, E., Anderson, B., Bradbury, J., DeGaetano, A., Troy, T.J., \& Wolfe, D. (2007). Past and future changes in climate and hydrological indicators in the US Northeast. Climate Dynamics, 28(4), 381-407.

Kunkel, K.E., Stevens, L.E., Stevens, S.E., Sun, L., Janssen, E., Wuebbles, D., Rennells, J., DeGaetano, A., \& Dobson, J.G. (2013). Regional climate trends and scenarios for the U.S. National Climate Assessment: Part 1: Climate of the Northeast U.S., NOAA Technical Report NESDIS.

Lipper, L., Thronton, P., Campbell, B.M., Baedeker, T., Braimoh, A., Bwalya, M., Caron, P., Cattaneo, A., Garrity, D., Henry, K., Hottle, R., Jackson, L., Jarvis, A., Kossam, F., Mann, W., McCarthy, N., Meybeck, A., Neufeldt, H., Remington, To., Sen, P.T., Sessa, R., Shula, R., Tibu, A., \& Torquebiau, E.F. (2014). Climate-smart agriculture for food security. Nature Climate Change, 4, 1068-1072.

Wolfe, DW, Comstock, J, Lakso, A, Chase, L, Fry, W, Petzoldt, C, Leichenko, R, \& Vancura, P. (2011). Agriculture. In W. S. C. Rosenzweig, A DeGaetano, M. O'Grady, S. Hassol, \& P. Grabhorn (Ed.), Responding to climate change in New York State: The ClimAID integrated assessment for effective climate change adaptation in New York State [Technical report]. Albany: New York State Energy Research and Development Authority (NYERSDA). Retrieved from www.nyserda.ny.gov/climaid

\section{Other resources}

Sustainable Agriculture Research \& Education (SARE). Grants and education to advance innovations in sustainable agriculture. Cover crops, Learning center. Accessed at www.sare.org/Learning-Center/ TopicRooms/Cover-Crops.

United States Department of Agriculture Northeast Climate Hub. Accessed at http://climatehubs.oce.usda. gov/northeast. 